\title{
Peristiwa Teater Tu(m)buh sebagai Konstruksi Politik Tubuh
}

\author{
Andi Taslim Saputra, I Nyoman Murtana \\ Program Studi Pengkajian Teater, \\ Program Pascasarjana, Institut Seni Indonesia (ISI) Surakarta \\ Jalan Ki Hajar Dewantara No. 19 Kentingan, Jebres, Surakarta 57126 \\ Email: taslimsaputra31@gmail.com
}

\begin{abstract}
Body politics is often positioned in the community and government institutions context, such as in military, hospitals, prisons, and so on. This study discusses body politics in a different context by reading a theatre phenomenon that creates a form of body politics in theatre with the focus on the "Tu(m)buh" work by Tony Broer. The application of the concept in Tony Broer's work differs from other actors, in expressing his ideas about the body's political construction. To answer the question of Tony Broer's body politics practice, it is used Foucault's disciplinary power concept. This research uses descriptive analysis research method. Data collection uses observation, documentation, and interview methods. The result shows Tony Broer employs the body politic practice in his "Tu(m)buh" artwork. The construction of Tony Broer's body formation is disciplined and it formed an intense, hard, and radical body. Tony Broer's actions create concepts and practices that show the body political image, both to oneself and to others so that the "Tu(m)buh"art work is the presentation of the body political construction.
\end{abstract}

Keywords: theatre, body politics, $t u(m) b u h$

\begin{abstract}
ABSTRAK
Politik tubuh kerap dimaknai dalam konteks institusi-institusi kemasyarakatan dan pemerintah, misalnya militer, rumah sakit, lapas, dan sebagainya. Kajian ini mendiskusikan politik tubuh dalam konteks yang berbeda, yakni membaca fenomena teater yang melahirkan bentuk politik tubuh dengan studi kasus Tu(m)buh karya Tony Broer. Penerapan kerja teater Tony Broer berbeda dari pelaku teater lainnya, dalam hal menuangkan gagasan dalam konstruksi politik tubuh. Untuk membaca persoalan praktik politik tubuh oleh Tony Broer digunakan konsep disciplinary power dari Foucault. Penelitian ini menggunakan metode penelitian deskriptif analisis. Sedangkan pengumpulan data dilakukan melalui observasi, dokumentasi, dan wawancara. Hasilnya menunjukkan bahwa Tony Broer menerapkan praktik politik tubuh dalam peristiwa teater $\mathrm{Tu}(\mathrm{m}) \mathrm{buh}$. Pembentukan kontruksi tubuh Tony Broer berupa pendisiplinan dan pembentukan tubuh yang intens, keras, dan radikal. Tindakan Tony Broer melahirkan konsep dan praktik yang memperlihatkan citra politik tubuh, baik terhadap diri sendiri maupun orang lain, sehingga peristiwa teater $\mathrm{Tu}(\mathrm{m}) \mathrm{buh}$ adalah kerja teater yang merupakan presentasi dari konstruksi politik tubuh.
\end{abstract}

Kata kunci: teater, politik tubuh, $t u(m) b u h$ 


\section{PENDAHULUAN}

Tubuh adalah keseluruhan yang melekat pada diri manusia, mulai dari mental, jiwa pikiran, rasa, perilaku, bahasa, penampilan, simbol, dan aktivitas sosial lainnya (Raditya, 2014: xiii). Terminologi mengenai tubuh sangat beragam berdasarkan letak geografis, suku, dan budaya. Bahkan, pembahasan mengenai tubuh tidak ada habisnya dalam kehidupan manusia, sehingga selalu relevan dalam berbagai keadaan. Tubuh memilliki aktivitas dengan daya jangkau yang luas, sehingga selalu dijadikan objek kekuasaan. Ketika berbicara tentang kekuasaan berarti stigmanya mengarah ke praktik politik.

Politik adalah disiplin ilmu yang menawarkan strategi untuk menguasai sesuatu. Ilmu politik berguna dalam membangun dan memperkokoh keberlanjutan dalam memangku jabatan. Dengan adanya politik, perbedaan persepsi sesama aktor politik tidak dapat dihindari. Aktor politik memiliki visi tersendiri yang harus dicapai meskipun tujuannya bertentangan dengan aktor lainnya (Faulks, 2012: 2).

Stigma politik kekuasaan yang sudah meretas ke dalam perlakuan fisik dan pendisiplinan yang dilaksanakan oleh para pemangku kuasa (baca: pemimpin) kepada masyarakat menjadi titik awal munculnya politik tubuh. Konsepsi tentang tubuh diletakkan pada ranah politik, tertanam dalam relasi kekuasaan yang membuatnya menjadi patuh dan produktif serta berguna secara politik-ekonomi (Kamahi, 2017: 123). Atas fenomena itu, Foucault (1997) mensinyalir politik tubuh sebagai berikut.

Momen historis disiplin tubuh adalah momen ketika seni mengenai tubuh manusia lahir. Bentuknya adalah suatu kebijakan pemaksaan atas tubuh, manipulasi sikap dan tingkah laku tubuh. Saat tubuh manusia masuk ke dalam mesin kekuasaan maka terjadi proses penyelidikan dan penataan kembali. Suatu anatomi politis sekaligus mekanika kekuasaan. Dengan demikian, disiplin menghasilkan tubuh-tubuh yang berkualitas, terlatih, dan taat (Synnott, 2007: 369).

Politik tubuh adalah sistem pengaturan atau teknologi politis terhadap tubuh, baik itu penghukuman maupun pendisiplinan (Foucault, 1995: 11). Politik tubuh sebenarnya berasal dari teknik kerja yang mengontrol tubuh. Istilah politik tubuh adalah salah satu kontribusi Foucault terhadap ilmu pengetahuan yang mendudukkan tubuh berelasi dengan kuasa dan pengetahuan sebagai objek penelitian.

Pengaturan politik tubuh yang berada pada tataran dalam, melalui dan atas tubuh fisik (Synnott, 2007: 369). Fenomena politik tubuh tidak hanya berkutat di dalam elemen-elemen kekuasaan pemerintahan, tetapi terjadi pada institusi-institusi, seperti penjara, rumah sakit, militer, ruang sipil, dan bengkel-bengkel kerja (Foucault, 1997: 307). Penulis melihat bahwa istilah politik tubuh juga ada dalam peristiwa kesenian.

Politik tubuh dalam ruang kesenian, khususnya teater, berujung pada praktik tubuh yang dibentuk dan dikontrol oleh tubuh fisik. Tubuh diupayakan mencapai tahap dikuasai oleh dirinya sendiri dengan cara dilatih, dikuasai, dan dikontrol. Konsepsi politik tubuh cenderung memperhatikan kondisi fisik manusia. Dengan kata lain, politik tubuh sama artinya dengan kuasa tubuh atau kontrol yang penuh, baik terhadap diri sendiri maupun orang lain.

Dalam konteks teater, penulis menegaskan bahwa pengertian politik tubuh adalah konsep teaterikal yang mengaplikasikan strategi politik yang berefek pada otoritas dalam mengontrol tubuh diri sendiri dan orang lain dengan sikap ikhlas maupun paksaan, sehingga memperlihatkan perilaku tubuh yang dilatih atau melatih, bertindak atau menindaki, disiplin atau mendisiplinkan serta diatur atau mengatur yang dijalankan pada keseharian, kemudian ditransformasikan ke dalam praktik teater. 
Merujuk politik tubuh yang diungkapkan oleh Foucault tersebut, praktik teater yang diaktualisasikan oleh Tony Broer, mengandung unsur atau sistem yang sama pada pola pelatihan dan praktik peristiwa teaternya. Kesamaan tersebut diproyeksikan melalui manusia yang memiliki otoritas kontrol terhadap tubuhnya. Misalnya, tubuh dibentuk, dilatih, dan memiliki kekuatan manusia di atas normal dan mendisiplinkan manusia lainnya. Dalam hal ini, penulis menegaskan bahwa pengertian politik tubuh merupakan konsep teaterikal yang mengaplikasikan metode pendisiplinan atau mempunyai otoritas dalam mengontrol tubuh diri sendiri dan orang lain, sehingga memperlihatkan bentuk kemampuan tubuh yang dilatih pada keseharian yang kemudian ditransformasikan ke dalam praktik peristiwa teater.

Tony Broer adalah seorang aktor teater Indonesia yang masih eksis sampai saat ini. Sejauh ini, dalam sejarah keaktoran di Indonesia, Tony Broer adalah seorang yang paling intens mendalami keaktoran dan mengeksplorasi secara totalitas metode yang menyangkut keaktoran. Dia dikenal sebagai aktor yang melakukan kerja teater yang fokus pada tubuh sebagai bahasa ungkap pertunjukan.

Karya Tony Broer yang berjudul $T u(m) b u h$, berawal dari karya yang dipergelarkan di halaman kampus ISI Yogyakarta tahun 2015 dengan judul Tumbuh Terbalik. Karya itulah cikal-bakal lahirnya $T u(m) b u h$. Adegan-adegan dari Tu(m)buh memiliki korelasi dengan karya Tumbuh Terbalik, sebagai bentuk karya lanjutan. Peristiwa teater $\mathrm{Tu}(\mathrm{m}) b u h$ karya Tony Broer disajikan melalui konsep imajinatif dengan muatan pertunjukan yang rumit untuk ditafsir (sejenis teater eksperimental). Peristiwa teater Tony Broer mensyaratkan relasi properti, artistik, dan tubuh. Daya tubuh, properti, dan lain-lain bersinergi dengan elemen-elemen di luar tubuh, yakni tubuh orang lain yang hadir dari peristiwanya.
Peristiwa tersebut mengacu kepada peristiwa-peristiwa tanda, seperti "metabahasa yang dapat dipakai untuk menganalisis bahasa-bahasa gambar, fisik, dan aural (auditif) dalam teater" (Sahid, 2016: 29). Peristiwa $\mathrm{Tu}(\mathrm{m})$ buh memproduksi tanda di setiap adegan. Menurut penulis, tanda-tanda tersebut mengambarkan politik tubuh pada peristiwa teater $T u(m) b u h$ karya Tony Broer.

Beroperasinya sistem teknologi politik tubuh yang dilakukan Tony Broer, dapat membantu disciplinary power Foucault menganalisis praktik teater Tony Broer. "Disciplinary power bekerja terhadap tubuh untuk mengendapkan normalisasi kekuasaan sebagai proses pembiasaan dalam tubuh terhadap perilaku dan menempatkan subjek sebagai efek dan kekuasaan terhadap tubuh" (Mudhoffir, 2013: 78-79). Oleh karena itu, terlahirnya nonsubjek (tanpa adanya figur yang dijadikan patokan) dalam kerja teater yang mendistribusikan politik tubuh sebagai kendaraan baru dalam pengetahuan teater hari ini.

Peristiwa teater $T u(m) b u h$ dijadikan objek kajian dengan alasan utama, bahwa dalam teater karya Tony Broer terjadi fenomena politik tubuh. Peneliti menganggap peristiwa teater $\mathrm{Tu}(\mathrm{m}) b u h$ merupakan kontruksi teaterikal yang membangun citra tubuh dan menyodorkan makna tubuh yang politis atau politik tubuh.

Makna politik tubuh tersebut menjadi alasan yang logis untuk dibahasakan dalam artikel ini. Penulis berasumsi bahwa terdapat pemaknaan tubuh yang politis, bukan dalam artian politik praktis seperti kajian teater yang sudah ada. Berdasarkan hal yang tersebut, maka menarik untuk mengungkap makna politis yang disampaikan dalam peristiwa $\mathrm{Tu}(\mathrm{m}) \mathrm{buh}$.

\section{METODE}

Kajian ini disusun menggunakan metode deskriptif analitik. Metode deskriptif analitik adalah metode yang melakukan 
langkah untuk mendeskripsikan objek sekaligus menganalisis (Ratna, 2010: 336). Metode deksriptif analitik digunakan untuk menguraikan bentuk kerja teater yang dilaksanakan oleh Tony Broer serta menguraikan makna politik tubuh yang terkandung dalam peristiwa teater Tony Broer.

Biasanya penelitian dilakukan di lingkungan kerja atau tempat asal peneliti, sehingga memperoleh informasi apa saja, termasuk masalah-masalah yang paling rahasia (Ratna, 2010: 220). Untuk mendapatkan data penelitian ini menggunakan metode penelitian kualitatif. Pengumpulan data dilakukan melalui observasi, dokumentasi, dan wawancara, serta selanjutnya dilakukan analisis data.

Penelitian ini fokus pada aktivitas pelatihan dan kerja penciptaan $T u(m) b u h$ karya Tony Broer yang dilaksanakan di Yogyakarta. Adapun untuk melengkapi data secara komprehensif, maka dilakukan studi observasi pastisipan dan sumber-sumber materi yang berkaitan dengan pemikiran pendisiplinan tubuh Michel Foucault, sehingga dapat ditemukan penggambaran disiplin tubuh yang dilaksanakan oleh Tony Broer dalam pelatihannya yang kemudian ditransformasikan ke dalam estetika pertunjukannya.

Hasil data yang diperoleh kemudian dianalisis menggunakan disciplinary power dari Michel Foucault, agar penggambaran mengenai politik tubuh dalam pelatihan yang memiliki relasi dengan konteks pertunjukan dapat diperoleh dan ditunjukkan secara konkret.

\section{HASIL DAN PEMBAHASAN}

\section{Politik Tubuh Tony Broer sebagai Proses Kreatif Teater Tu(m)buh}

Penerapan sistem pendisiplinan tubuh telah dipercaya membuat tubuh dapat dikontrol, tubuh yang patuh, tubuh yang mampu diajak berkompromi dengan pikiran. Menurut Foucault, disiplin adalah pelaksanaan kehendak atas paksaan dari orang lain, tetapi disiplin merupakan pelaksanaan atas kehendak diri sendiri (Hardiansyah, 2012: 69). Sebagaimana konsep disiplin tubuh, tubuh menginginkan suatu yang otonom dari kehadiran bahasa sebagai media ungkap manusia. Penaklukan terhadap tubuh tersebut menjadi suatu pengetahuan terhadap tubuh, sehingga kedua elemen penting inilah yang menegakkan tekhnologi politis terhadap tubuh (Misbah, 2017: 164).

Perlu dicatat bahwa bentuk yang dimaksud bukanlah disiplin monastik (kebutuhan keselamatan), akan tetapi disiplin yang lebih ditujukan sebagai pengembangan penguasaan individu terhadap tubuhnya sendiri (Hardiansyah, 2012: 69). Sifat tubuh yang berusaha meningkatkan performa adalah dorongan dari usaha tubuh yang disiplin. Dalam kasus ini subyek yang tadinya memiliki keterbatasan, dengan adanya metode pendisiplinan akan membuka potensi daya jangkauan tubuh.

Reproduksi pendisiplinan tubuh memiliki misi yang sama yakni menjadikan tubuh yang patuh dan terkendali. Praktik tubuh seperti ini terjadi dimana-mana, seperti di sekolah, akademi militer, pusat rehabilitas, rumah tahanan, rumah sakit, pelatihan teater, pelatihan olahraga, kamp konsentrasi, dan lain sebagainya (Foucault, 1997: 307). Setiap penghuni harus mematuhi peraturan yang berlaku, sehingga praktik pendisiplinan yang menjadikan tubuh patuh merupakan metode politik tubuh. Disiplin tubuh menjadi suatu kekuatan yang patuh dan berguna serta menjadi tubuh yang produktif (Mustofa, 2017: 164).

Praktik kesenian bahkan melakukan metode politik tubuh yang serupa, misalnya dalam konteks pendisiplinan tubuh yang ketat berujung pada praktik pelatihan dan peristiwa teater Tony Broer. Latihannya menyiratkan metode politik tubuh yang ditransformasikan ke dalam rutinitas sehariharinya maupun peristiwa teaternya. 


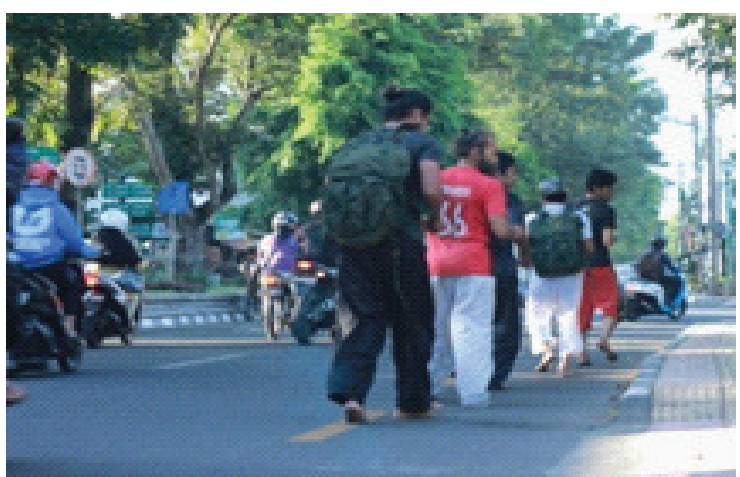

Gambar 1. Politik tubuh dalam pelatihan tubuh teater Tony Broer.

(Sumber: dokumentasi Taslim, 2017).

Pelatihan Tony Broer juga melakukan metode atau model yang sama. Yakni, terdapat perilaku yang wajib dikerjakan dan dilakukan berulang-ulang. Perilaku yang berulang tersebut menandakan sifat yang diprogramkan untuk ditanamkan ke dalam perilaku otomatis ke dalam sistem tubuh. Sikap melakukan berulang-ulang berguna untuk kemampuan tubuh yang bertambah dan berkembang dalam hal kekuatan.

Pada pukul 15:00 WIB, Tony Broer memulai perenggangan otot tubuh. Pada proses awal, dia berlari dengan jarak tempuh 20 meter di halaman kampus Pascasarjana ISI Yogyakarta. Berlari dilakukan dengan hadap tubuh empat penjuru yang dilakukan secara bergantian. Setelah berlari, dilanjutkan dengan melatih tubuh dengan sit-up dan push-up sebanyak 20 kali atau lebih. Aktivitas tersebut seperti terlihat pada gambar 1 .

Setelah latihan di halaman Pascasarjana ISI Yogyakarta selesai, barulah Tony Broer mengambil tas hijau dengan beban $35 \mathrm{~kg}$. Tas tersebut dipakai berlarian di ruang publik. Rute berlari tersebut berjarak kurang lebih $15 \mathrm{~km}$ sambil menggendong tas. Pada rute berlari terdapat empat titik perhentian.Setiap titik perhentian tersebut melakukan sikap tubuh sit-up sebanyak 25 kali, push-up sebanyak 25 kali, dan melakukan yoga (pengaturan nafas dan sikap head stand).
Ruang kerja tubuh yang diprogramkan oleh Tony Broer berisi orang-orang yang berbeda latarbelakang disiplin ilmu. Berteater tidak melulu harus merekrut pemain yang murni teater, karena semua orang berpotensi menjadi aktor. Misalnya, orang tersebut dari disiplin teater, fotografer, tari, bahasa, sastra, manajemen seni pertunjukan, Sekolah Menengah Atas, musik, film, seniman rupa, dan sebagainya.

Tubuh yang berlatih ini tidak mempelajari satu karakter tubuh sebagai objek. Tubuh yang dipelajarinya adalah tubuhnya sendiri sebagai tubuh subyek untuk dikembangkan. Menyadarkan kepada tubuhnya bahwa dari masing-masing tubuh ini memiliki karakteristik tubuh-tubuh yang perform (tubuh pertunjukan). Dari perbedaan karakteristik tersebut, tubuh memproyeksikan nuansa yang beragam (tubuh indentitas) sesuai dengan latar belakang kebertubuhannya, dengan visi menggali esensi tubuhnya.

Sikap pendisiplinan tubuh dalam praktik teater Tony Broer adalah sikap awal seorang aktor dalam proses kreatifnya menuju tubuh yang ideal dan berguna untuk keaktoran. Aktor berserah diri menjalani latihan berat bahkan latihan yang paling ekstrim sekalipun, asalkan berhubungan dengan kematangan menjadi aktor yang ideal.

Tubuh berperan sentral sebagai media pokok dalam teater tubuh. Dengan demikian, untuk mendapatkan hasil yang bagus, maka dilakukan pendisiplinan tubuh. Metode pendisiplinan tubuh mencoba mengolah tubuh dari segi kepekaan, kelenturan, kekuatan, kecepatan, ketahanan, keluasan, dan kemampuan. Kegiatan-kegiatan tersebut mempunyai kriteria keilmiahan yang menjadi ukuran kebenaran, yang pada gilirannya membentuk individu (Haryatmoko, 2016: 16).

Pencapaian yang diharapkan tentu saja berhubungan dengan performa fisik. 
Meskipun proses tubuh terdapat kesamaan dalam konteks militer atau bentuk yang lainnya, dalam hal ini proses pendisiplinan ketubuhan Tony Broer mengambil hal yang berbeda. Yaitu, pendisiplinan tubuh berada pada tatanan proses eksplorasi tubuh yang digunakan untuk kebutuhan performance (pertunjukan). Lebih tepatnya, disiplin tubuh yang dilahirkan dalam konteks gagasan peristiwa teater.

Sifat tubuh yang berusaha meningkatkan performa adalah dorongan dari usaha tubuh yang disiplin. Dalam kasus ini, subjek yang tadinya memiliki keterbatasan, dengan adanya metode pendisiplinan membuka potensi daya jangkauan tubuh.

Proses politik tubuh menjadi bagian penting dalam praktik teater Tony Broer, yang dikerjakan tiga kali atau lebih dalam seminggu. Tentunya kerja teater Tony Broer berangkat dari pola disiplin sebagai rangkaian dari proses kreatifnya. Andi (26 tahun), salah seorang yang aktif mengikuti pelatihan keaktoran Tony Broer, yang juga mahasiswa Fotografi Pascasarjana ISI Yogyakarta, menjelaskan pola pendisiplinan yang dilakukan selama mengikuti proses teater Tony Broer sebagai berikut.

Pertama, tubuh melakukan pemanasan dengan berlari-lari kecil, di depan kampus (pascasarjana ISI Jogja) kurang lebih 100 m, kemudian push-up dan sit-up. Minggu pertama biasanya lari dulu tanpa beban, itupun tidak terlalu jauh, kira-kira $10 \mathrm{~km}$, itupun selalu ada jeda, tiap dua $\mathrm{km}$ kemudian jeda, merenggangkan tubuh, sit-up, push up dan kemudian olah pernapasan.

Tahapan kedua, lebih keras dari sebelumnya. Tahapan ini mencoba membawa beban, karena kita masih belum tahu sampai dimana kemampuan tubuh kita, tapi kadang kalau kita ada tim tiga orang maka dilakukan secara bergantian membawa beban itu. Berat bobot tas yang dipikul sekitar $35-45 \mathrm{~kg}$, dengan latihan sit-up dan pushup tiap jeda, panas-panasan di jalan tanpa menggunakan sepatu atau alas kaki (Andi, wawancara tanggal 5 Mei 2017).

Melatih tubuh secara kontuinitas dan dilatih dengan bersungguh-sungguh sampai mendorong tubuh melewati batas kemam- puan standar, seperti digambarkan dalam kutipan di atas, adalah bagian dari upaya membongkar dan mempertanyakan kembali eksistensi kebertubuhan aktor. Latihan dengan jalan mendisiplinkan tubuh seperti yang dilakukan Tony Broer memang tidak seperti latihan teater pada umumnya, tidak berada dalam ruang tertutup atau ataupun berkaca di depan cermin lalu mengolah bentuk mimik, bahkan melihat lekukan atau elastisitas tubuh. Sistem latihan yang dikerjakan Tony Broer adalah sistem yang membongkar bentuk pelatihan teater, lebih tepatnya, sistem politik tubuh.

Bentuk latihan tersebut berada pada ruang publik. Dapat dikatakan bahwa proses latihan yang dilakukan bersentuhan atau berinteraksi langsung dengan manusia, tumbuhan, benda, dan binatang di ruang publik. Ikbal, seorang yang menjadi pelaku pelatihan keaktoran sekaligus aktor Tony Broer dalam beberapa pertunjukannya, mendeksripsikan kondisi saat mengalami pendisiplinan yang dilakukan saat latihan bersama Tony Broer sebagai berikut.

Saat itu, kami bertemu dengan berbagai macam rutinitas yang ada dipublik, berinteraksi juga kalau ada yang menyapa. Bahkan, kami membaca tumbuhan dan beberapa perangkat sarana yang ada diruang publik. Misalnya, kami merespon kursi, kayu, tanaman, hewan, dan benda-benda lainnya (Ikbal, wawancara tanggal 7 Mei 2017).

Proses eksplorasi tubuh dalam keadaan pendisiplinan secara khusus mengelola praktik ketubuhan secara radikal, teratur, konsistensi, dan intens. Latihan dengan model yang seperti ini memang keras dan monoton, tetapi disini terdapat capaian yang meletakkan dasar untuk menyadarkan tubuh sebagai tubuh performance (pertunjukan). Bahkan, orang yang melihat proses latihan ini menganggap sebagai sebuah pertunjukan. Rizal adalah seorang yang paling aktif mengikuti latihan tubuh Tony Broer bercerita sebagai berikut.

Bang Broer itu membuat pertunjukan setiap seminggu tiga kali. Pertunjukan yang di- 
maksud adalah kami yang sedang melakukan rutinitas (latihan) di jalan, dilihat dan penontonnya banyak gitukan. Secara tidak sadar, penonton itu banyak yang menunggu. Kalau misalnya, aku lagi beli makan siang di tempat langganan dekat lampu merah. Mereka bertanya, "Mas kapan pertunjukan lagi?"\ Jarang kelihatan." Saya salat di mesjid di barisan depan, kadang orang nanya, mas yang suka lari yah? Kapan mentas di jalannya lagi? Seperti itu pertanyaan-pertanyaan yang saya jumpai ketika bertemu dengan orang-orang yang sering melihat kami (Rizal, wawancara 20 Mei 2017).

Perspektif yang dibangun seperti yang diceritakan Rizal menyodorkan gagasan dari tubuh manusia. Menurut Tony Broer, tubuh disiplin akan melahirkan gagasan tubuh dan kesadaran pada tubuh yang sebenarnya (Broer, wawancara 20 Mei 2017). Secara garis besar, tubuh mempersepsikan gagasan bebas terhadap mereka yang melakukan aktivitas dan yang melihat rutinitas latihan di ruang publik.

Dengan demikian, manusia lainnya menanggapi rangsangan tubuh (dalam porsi artistik tertentu) yang bereaksi terhadap pembentukan gagasan. Sederhananya, tubuh berusaha menawarkan gagasan yang mampu dibaca atau disimpulkan oleh manusia lainnya. Dalam tataran ini, gagasan yang dimaksud adalah citra. Pandangan citra itu bisa bermacam-macam, tetapi dalam hal ini citra ini dapat berupa citra kengerian; citra kekerasan; citra kesedihan; citra ketakjuban; dan citra politis tubuh yang dinarasikan oleh tubuh.

\section{Pembentukan Ketubuhan Tony Broer dalam Teater}

Kehidupan berbudaya mengalami beragam pembentukan yang diinisiasi oleh kaidah-kaidah adat, hukum, dan agama. Manusia sebagai subyek yang menjalani pembentukan tersebut, secara langsung menjalani kehidupan yang diintervensi beragam peraturan. Metode pembentukan sosial ini dipergunakan untuk membangun sistem reproduksi perilaku manusia serta menjadi kebenaran manusia yang selalu dilaksanakan dalam hidup bermasyarakat. Oleh karena itu, kehidupan manusia dibentuk oleh warisan sifat, sikap, dan kebiasaan yang diperoleh dari pengalaman ketubuhan terhadap sekitar.

Begitu pula pembentukan tubuh Tony Broer dalam membangun dan mengaplikasikan pemahaman terhadap proses kerja kreatif teaternya. Pembentukan yang dimaksud direalisasikan dari segi fisik manusia, bahkan dalam ranah estetik. Dalam estetika pertunjukan, konten dari pembentukan tidak melulu berbicara mengenai keindahan, tetapi juga berbicara sesuatu yang tidak indah. Bahkan, sekalipun pembentukan tersebut keras, menakutkan dan menyakitkan, itu tidak menjadi penghalang untuk melaksanakannya. Pembentukan ketubuhan ini berbicara tentang hasil apa yang dicapai ketika melakukannya serta manfaatnya.

Upaya pembentukan dilakukan dengan cara mengamati, mengindentifikasi, menginterogasi, dan merealisasikannya. Hal itu sebagai bentuk formula yang dipraktikkan. Sebagai bentuk yang memiliki relasi dengan situasi dan kondisi, maka pembentukan yang ditonjolkan, yakni berbicara sesuatu hal yang dibaca sesuai waktu itu, sehingga praktik pembentukan ketubuhan mengacu secara kontekstual.

Karya yang dibuat Tony Broer adalah pembacaan mengenai realitas. Dengan kata lain, tubuh mengandung cerminan fenomena konflik yang terjadi. Dengan menggunakan mekanisme-mekanisme pembentukan tubuh yang dijalankan secara intens dan teratur.

Dalam model pembentukan tubuh Tony Broer, dilakukan menyerupai bentuk pelatihan militer, sehingga memperoleh citra ketubuhan yang politis (disiplin). Saat ini, pembentukan tubuh Tony Broer paling tepat dinyatakan sebagai pembentukan yang menanggap kondisi zaman yang kekinian (baca: mengikuti kondisi zaman, misalnya 
problem digital). Dengan demikian, yang dimaksud pembentukan dengan model kekinian adalah kritik dan respon terhadap manusia dengan tubuh urbannya.

Tubuh urban diibaratkan sebagai manusia yang bergerak dengan beragam kesatuan yang dibingkai persoalan logika ekonomi, politik, teknologi informasi dan lain sebagainya. Tony Broer menceritakan pembentukan tubuhnya sebagai berikut.

Sebenarnya, ini pengamatan di luar tubuh saya. Anggapannya bisa jadi pembentukan-pembentukan tubuh saya pada periode tertentu, misalnya tubuh pasca reformasi, ataupun kondisi zaman lainnya. Jadi, pembentukan tubuh merepresentasikan situasi dan waktu pertunjukan yang ditampilkan pada fase tertentu. Contohnya, pada saat pertunjukan di kelompok Payung Hitam dengan karya Gong, Kaspar, Merah Putih Bolong Boblong. Karya-karya itu representasi dari pembentukan tubuh Orde Baru. Akhirnya, orang mengklasifikasikan tubuh saya ini pada fase itu. Untuk saat ini, pembentukan tubuh saya berkutat pada pembentukan tubuh sebagai tubuh sosial, dalam konteks sosial urban. Contohnya, urban itu tumpang-tindihlah, tradisional enggak, modern enggak, intervensi televisi, pengetahuan tidak berkelanjutan tapi bertubi-tubi datangnya, saya ngeliat dance, ngeliat ini, itu. Nah, itu secara tidak disadari fenomena tersebut membentuk tubuh saya, lebih kesitu sebenarnya, menurut saya gitu. Tubuh saya mengklaim kondisi ruang dan waktu, dibentuk pada periode itu. Konteksnya lebih mengarah kesana (Broer, wawancara tanggal 20 Mei 2017).

Beragam persoalan yang dialami Tony Broer ternyata memiliki peran yang secara signifikan membentuk ketubuhannya. Artinya, pembentukan tubuh Tony Broer sebagai perwujudan dari realitas kondisi zaman sebagai idiom teaternya. Pada akhirnya, pembentukan tubuh Tony Broer mengedepankan tubuh yang mampu dikontrol, jinak terhadap keinginannya, dan tubuh yang bereaksi dengan sendirinya.

\section{Presentasi Politik Tubuh}

Sejak abad ke-17, ketika pendapatpendapat tentang keaktoran mulai dicatat dalam buku-buku harian, surat, dan kemu- dian esai-esai, terdapat dua pendekatan akting yang berbeda yakni pendekatan akting representasi (formalisme) dan akting presentasi (realisme) (Sitorus, 2002: 18). Wujud presentasi dan representasi sudah terlacak dan mulai dibicarakan. Bahkan, dalam suatu waktu keduanya terbilang berbeda, sebab keduanya memiliki spesifikasi dasar dalam menentukan bentuknya. Perbedaan representasi dan presentasi dapat dilihat dari apa yang ditunjukkan oleh sebuah karya seni. Penulis, dalam hal ini, lebih mempertebal persoalan wujud karya yang bergenre presentasi.

Presentasi adalah pengungkapan secara langsung tanpa pretensi terhadap sebuah wujud. Presentasi dalam peristiwa keseharian seperti seorang pemateri yang berkoarkoar di acara seminar. Pada pendekatan presentasi dalam akting tidak jauh berbeda dari bentuk presentasi pemateri dalam seminar. Artinya, wujud yang ingin dihadirkan adalah wujud sebenarnya dari bentuk riil dan menyampaikan sikap spontan dalam menghadapi peserta acara. Pendekatan presentasi mengutamakan identifikasi antara jiwa si aktor dan jiwa si karakter sekaligus memberikan kesempatan tingkah laku untuk berkembang (Sitorus, 2002: 29). Keaktoran dalam akting berusaha untuk menjadi karakter tokoh yang diamatinya.

Pelopor akting presentasi seperti ini adalah Stanislavski. Dalam buku Art of Acting: Seni Peran untuk Teater, Film, \& TV karya Sitorus (2002) menyatakan bahwa ciri khas yang ditawarkan sistem presentasi dari Konstantin Stanislavsky sebagai berikut.

Penemuan Stanislavsky ini didasari oleh pengertiannya tentang bagaimana aktor-aktor besar yang menjadi bahannya, mengaplikasikan suasana psikologi dari perjuangan hidup mereka terhadap stimuli-stimuli emosional, fisikal dan mental serta tindakan-tindakan mereka yang menjadi akibat dari respon-respon tersebut (Sitorus, 2002: 30).

Bentuk presentasi yang dikembangkan oleh Tony Broer berbeda, seperti yang di- 
paparkan sebelumnya bahwa "presentasi keaktoran oleh Stanislavsky di separuh abad ke-18 sampai memasuki abad ke-19 adalah keaktoran mewujudkan karakter orang lain" (Sitorus, 2002: 31). Tony Broer mensyaratkan model peristiwa teaternya dengan mengembangkan makna citra politik tubuh, tubuh tidak meniru tokoh akan tetapi tubuh yang mengalami. Dengan spesifikasi pada bentuk, politik tubuh memberikan nuansa yang baru dalam produksi teater hari ini.

Perwujudan politik tubuh diharapkan dapat melahirkan tubuh yang bermanfaat bagi yang melaksanakannya. Pada tataran ini, subyek tidak lagi hadir dengan tubuhnya yang alami, bahkan menjadi tubuh yang digunakan atas kehendak (kehendak diri sendiri atau orang lain). Misalnya, yang digambarkan oleh Tony Broer dari karya $T u(m) b u h$ berupa corak politik tubuh. Aktor dan penonton sebagai materi peristiwa menampilkan bentuk atraksi atau ajang menampilkan keahlian daya kerja tubuh, sehingga corak teater yang dipresentasikan tergolong jenis/bentuk baru, atau berbeda dari sebelumnya.

Peralihan dari satu sistem tanda ke sistem tanda yang lainnya merupakan bentuk pengapresiasian, pelestarian, atau nostalgia terhadap pertandaan referensi atau pertandaan kemasalaluan yang dikutib bahkan makna lain yang baru (Denissa dkk., 2016: 435). Kerja teater Tony Broer bukanlah sebuah bentuk yang merusak bentuk pemaknaan yang telah mapan (dalam konvensi metode Stanislavsky). Dengan merujuk Denissa dkk. (2016) dapat disimpulkan bahwa bentuk presentasinya adalah pemaknaan yang baru dengan output tubuh yang mengalami pengalaman politik tubuh bukanlah tubuh yang menjadi karakter orang lain.

Politik tubuh kadangkala dikaitkan dengan praktik-praktik kultural, kesenian, dan diskursus manusia. Pada sisi tertentu, Foucault berhasil menemukan tesis yang berhubungan dengan pendisiplinan tubuh.

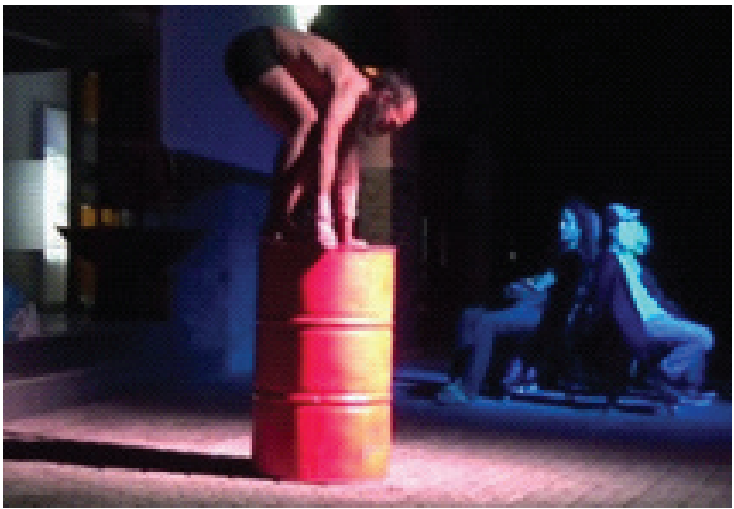

Gambar 2. Politik tubuh pada dirinya sendiri peristiwa $T u(m) b u h$.

(Sumber: Capture video dokumentasi Tony Broer, 2016).

Studi penelitian Foucaut membicarakan tubuh yang berelasi dengan kekuasaan (power) dan pengetahuan (knowledge). Syaputra menyatakan bahwa tidak ada kekuasaan yang terlahir tanpa pengetahuan, begitupun sebaliknya (Syaputra, 2013: 183). Artinya, produksi kuasa akan selalu diikuti pengetahuan dimanapun konteksnya. Sebaliknya, pengetahuan akan selalu memproduksi kekuasaan.

Kenyataannya, politik tubuh yang dimaksud Foucault, berhubungan dengan praktik sosial, atau lebih tepatnya mengenai pengaplikasian prinsip pengaturan yang dibentuk oleh kekuasaan. Pada dasarnya tubuh selalu berkaitan dengan kuasa tubuh yang berkesinambungan dengan kekuasaan pada praktik keseharian manusia. Dalam hal ini, subyek berkuasa atas dirinya sendiri atau menguasai subyek lainnya.

Pada konteks peristiwa Tu(m)buh, Tony Broer mengaplikasikan dua bentuk politik tubuh (baca: otoritas terhadap dirinya dan orang lain). Bentuk politik tubuh terhadap dirinya berupa adegan tubuh berjenggot yang menyiksa diri, berguling, serta mengurung diri dalam drum. Terdapat bentuk politik tubuh terhadap orang lain, yakni tubuh mereka diikat, dikontrol dan terjebak dalam aturan main tubuh berjenggot dari awal hingga akhir peristiwa teater (lihat gambar 2). 
Mekanisme kontrol pembentukan individu yang patuh dan berdisiplin adalah wujud kekuasaan dimana-mana (Syaputra, 2013: 182). Berkenaan dengan itu, prinsip pengaturan (kontrol politis tubuh) bisa saja berada pada tataran diskursus yang berhubungan dengan praktik kesenian. Peristiwa Tu(m)buh mencerminkan kontrol tubuh yang tumbuh dan melahirkan politik tubuh.

Terdapat dua kemungkinan dari ekspresi tubuh yang ditampakkan pada adegan tersebut, yakni kemungkinan pertama adalah bentuk tubuh yang memperlihatkan tubuh cerdas, tubuh ekstrem, dan tubuh yang peka (responsif). Sebut saja tubuh berjenggot menghadirkan monisme tubuh -kepercayaan yang difokuskan pada kemampuan tubuh.

Pembendaharaan Tony Broer, selaku aktor berjenggot, memperlihatkan kemampuan tubuh yang ditampakkan bukanlah hal yang begitu saja ada, tetapi melakukan bentuk kontrol atau pendisiplinan tubuh yang keras dan radikal. Adegan tersebut mengambarkan keadaan tubuh yang menanggalkan kuasa kata, seperti terlihat pada gambar 2 .

Tubuh hadir pada ruang yang bebas dari kata. Kata yang kadang membelenggu daya pikat tubuh. Kemudian dalam peristiwa $T u(m) b u h$, keadaan tersebut menandakan kekuatan teknik politis tubuh. Tubuh berperan untuk membelenggu kehadiran kata, kemudian mengedepankan segi kemampuan dan keahlian tubuh manusia.

Pembentukan seperti itu mirip yang dilakukan oleh teknik politis tubuh di lingkungan atau pelatihan tentara yang dibentuk oleh kekuasaan tertentu. Foucault memaparkan perilaku-perilaku yang berhubungan dengan pendisiplinan sebagai berikut.

"The machine required can be constructedl posture is gradually correctedl a calculated constraint runs slowly through each part of the body, mastering it, making it pliable, ready at all times, turning silently into the automatism of habit. Re- cruits become accustomed to 'holding their heads high and erect; to standing upright, without bending the back" (Foucault, 1995: 135).

Tubuh yang tercipta pada paparan di atas juga muncul pada perlakuan tubuh yang dilakukan Tony Broer dari pertunjukan $T u(m) b u h$. Tony Broer memberlakukan sistem politik tubuh yang secara bertahap dilakukan. Penyadaran tubuh atas sistem disiplin tersebut mampu mengontrol tubuh, persis dengan para militer yang memproduksi sistem ketubuhannya.

Mekanisme kontrol pembentukan individu yang patuh dan berdisiplin adalah wujud kekuasaan di mana-mana (Syaputra, 2013: 182). Berkenaan dengan itu, prinsip pengaturan (kontrol politik tubuh) bisa saja berada pada tataran diskursus yang berhubungan dengan praktik kesenian. Peristiwa Tu(m)buh mencerminkan politik tubuh yang tumbuh dan melahirkan tubuh yang terkontrol dan mengontrol bagi yang mempraktikannya. Tingkah laku politik tubuh tergambarkan pada peristiwa $\mathrm{Tu}(m) b u h$.

Kemungkinan kedua, berhubungan dengan model politik tubuh atau kuasa tubuh terhadap orang lain. Pada titik ini, kehadiran penonton di ruang yang tersentuh oleh aktor, memungkinkan terjadinya tindakan atau faktor yang menggunakan orang tersebut untuk kepentingan tertentu. Bentuk tersebut menandakan, praktik kerja yang membawa kekuasaan terhadap orang lain. Foucault memaparkan, bahwa teknologi politis terhadap tubuh untuk menjadikan individu patuh dan berguna, mekanisme seperti inilah pengetahuan atas individu lahir (Foucault, 1997: 74).

Peristiwa teater $\mathrm{Tu}(\mathrm{m})$ buh mempresentasikan metode pendisiplinan tubuh yang diterapkan oleh individu terhadap individu lainnya yang ditunjukkan pada praktik kesenian, khususnya peristiwa $\mathrm{Tu}(\mathrm{m}) \mathrm{buh}$. Hasilnya, individu berusaha untuk mencapai kehendaknya terhadap objek pendisiplinan, minimal melaksanakan teknolo- 


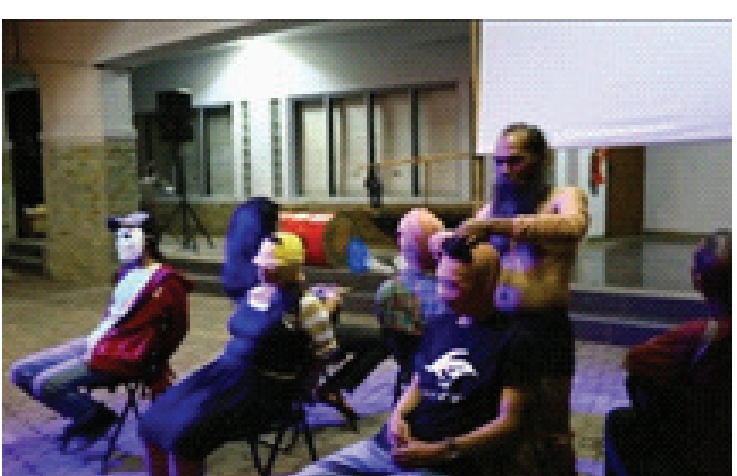

Gambar 3. Politik tubuh terhadap orang lain peristiwa teater $\mathrm{Tu}(\mathrm{m}) \mathrm{buh}$.

(Sumber: Dokumentasi Andi, 2016).

gi politis untuk menyempurnakan pola teknikal yang dimilikinya terhadap orang lain. Dalam arti, sebagai pembentuk keahlian fisikal tubuh dari dirinya untuk orang lain, sehingga terjadilah sifat otoritas tubuh atas orang lain. Seseorang akan mempunyai kuasa terhadap orang lain ketika dia punya peranan yang kuat dalam satu arena, seperti yang terlihat pada gambar 3 .

Perwujudan politik tubuh diharapkan melahirkan tubuh yang bermanfaat bagi yang melaksanakannya. Pada tataran ini, subyek tidak lagi hadir dengan tubuhnya yang alami, bahkan menjadi tubuh yang digunakan atas kehendak (kehendak diri sendiri atau orang lain). Misalnya, yang digambarkan oleh Tony Broer dari karya $\mathrm{Tu}(\mathrm{m})$ buh berupa corak politik tubuh. Aktor dan penonton sebagai materi peristiwa menampilkan bentuk atraksi atau ajang menampilkan keahlian daya kerja tubuh, sehingga corak teater yang dipresentasikan tergolong praktik politik tubuh, yang berbeda dari sebelumnya.

Penggunaan tubuh dalam peristiwa teater $T u(m) b u h$ disejajarkan dengan praktik politik tubuh yang dibentuk oleh kebiasaan pelatihan tentara, dalam arti keduanya memiliki pola yang sama. Secara tekstual pertunjukan, bahan peristiwa $\mathrm{Tu}(\mathrm{m}) b u h$ mengambil perilaku keseharian (dalam konteks proses penciptaan) yang mencerminkan pelatihan tentara, sehingga
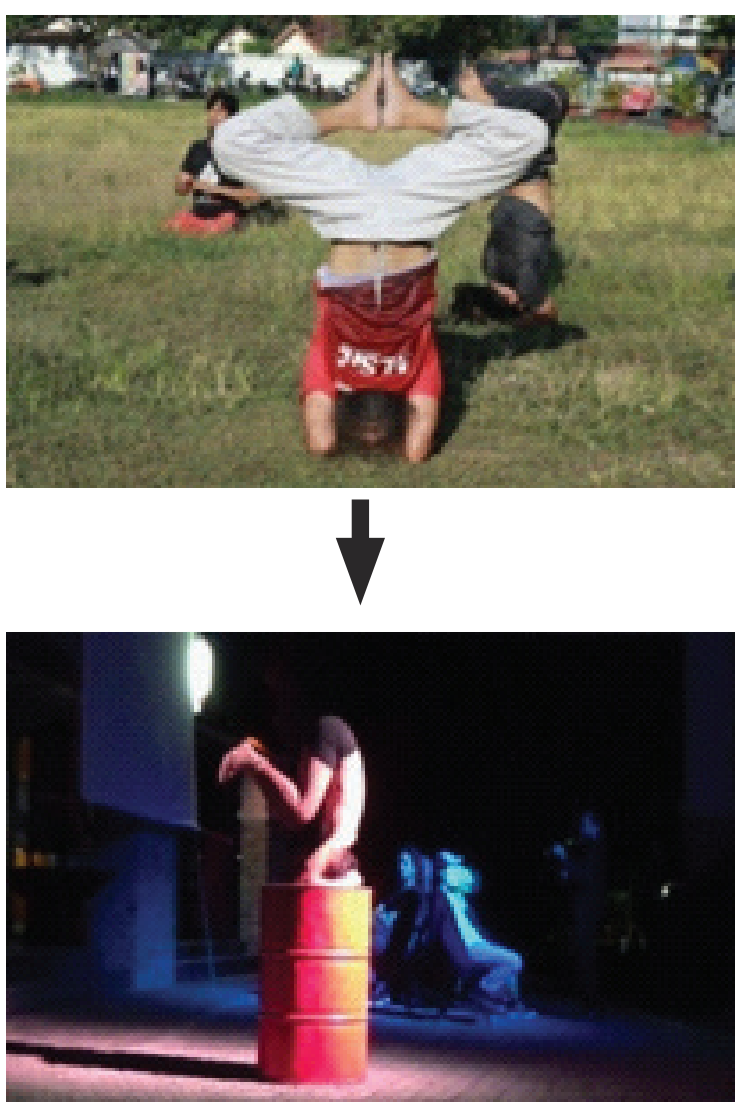

Gambar 4. Politik tubuh dalam keseharian ditransformasikan ke bentuk peristiwa $T u(m) b u h$. (Sumber: Dokumentasi Pribadi Tony Broer, 2016).

outputnya adalah terjadi praktik otoritas tubuh atas pikiran tampak lebih dominan. Jika ditarik pada peristiwa teater $T u(m) b u h$, tubuh termedisiasi oleh gagasan praktik politik tubuh. Bentuk politik tubuh tersebut merupakan kontuinitas atau bentuk transformasi dari keseharian yang mengalami tindakan pelatihan-pelatihan tubuh yang keras, disiplin, intens, radikal, dan terpola - peristiwa keseharian menjajaki perilaku pelatihan tubuh yang terus-menerus (lihat gambar 4).

Dengan kata lain, usaha perilaku ketubuhan berkutat pada perilaku yang otomatis (kontrol tubuh yang dominan). Artinya, politik tubuh sebagai model/penyajian perilaku tubuh yang lebih otonom dari segala elemen yang ada. Sebagai bukti peristiwa keseharian menjadi usaha tubuh melampaui kekuatan pikiran dengan jalan politik tubuh sebagai berikut. 
Pola teknik keseharian tersebut tidak lain adalah latihan yang keras, intens, dan tidak menanggalkan arti sebuah proses. Latihan menjadi satu-satunya upacara yang penting untuk menaklukkan tubuh (Foucault, 1997: 76). Pada sisi ini, tubuh dijadikan objek yang dilatih terus-menerus guna mendapatkan bentuk tubuh yang elastis, kekar, dan berotot. Metode latihan sebagai alternatif satu-satunya untuk mempercayai tubuh. Disisi lain, usaha pelatihan tubuh juga berupaya mematikan kepekaan pikiran. Jika diidentifikasi secara mendalam, Tony Broer menaruh kepercayaan terhadap tubuh. Efek kepercayaan didapatkan dari proses latihan.

Di samping itu, secara umum peristiwa daya ungkap berawal dari kerja pikiran. Pihak ini beranggapan bahwa pikiran selalu berperan penting ketika manusia melakukan aktivitas. Dalam konteks peristiwa teater $T u(m) b u h$, bentuk yang ditawarkan Tony Broer tidak sesuai dengan stigma tersebut, akan tetapi lebih mengarah kepada tubuh yang mendahului kerja sebuah pikiran. Kesimpulan logisnya, proses kerja di mana tubuh bereaksi lebih dahulu sebelum pikiran.

Pertalian antara manusia dengan dunia pertama-tama diawali dan terjadi lewat tubuhnya bukan melalui pikirannya (Simatupang, 2013: 53). Lebih dalam lagi, keberadaan lebih bersifat tubuh lebih dulu menyimpulkan daripada apa yang diinginkan oleh pikiran. Bahkan, hal ini melampaui keinginan kerja dari sebuah pikiran yang selama ini selalu bergerak atau berkerja lebih dulu sebelum tubuh.

Metode latihan politik tubuh, bagi Tony Broer, dijadikan alternatif satu-satunya untuk mempercayai tubuh. Di sisi lain, usaha pelatihan tubuh juga berupaya mematikan kepekaan pikiran. Jika diidentifikasi secara mendalam, Tony Broer menaruh kepercayaan terhadap tubuh. Efek kepercayaan didapatkan dari proses latihan. Dominannya tubuh dapat dilihat dari cara dia memperlakukan tubuh.

Dengan demikian, bentuk ini menjadi sebuah bentuk yang dipresentasikan. Seperti kegelisahan Artaud terhadap teks teater yang telah mendominasi panggung dan aktor selama bertahun-tahun di seluruh daratan eropa (Artaud, 2009: vii). Kerja teater Artaud mensyaratkan kata-kata tidak tumbuh mendominasi.

Kata tidak lagi berperan sentral dalam bahasa ungkap pertunjukan, yang tumbuh adalah fisikal tubuh yang bergerak lebih leluasa dan otonom dari kata-kata dan pikiran. Namun, tindakan ini bukanlah sebuah pengerdilan terhadap kata, tetapi lebih kepada usaha tubuh untuk tumbuh dan menjangkau praktik politik tubuh. Dalam hal ini, tubuh diposisikan menjadi kata/bahasa ungkap dalam peristiwa teater $\mathrm{Tu}(\mathrm{m}) \mathrm{buh}$. Menurut Supartono, penciptaan teater tubuh yang memposisikan tubuh sebagai bahasa/kata dijelaskan sebagai berikut.

Penciptaan teater tubuh diartikan sebagai pemaknaan dari tubuh itu sendiri. Dimulai dari bahasa tubuh, lalu lahir kata dan kembali pada tubuh yang sampai sekarang masih terus dieksplorasi menjadi media utama teater. Ini merupakan rangkaian proses kesadaran tentang "tubuh" yang harus dikonsepkan dengan bahasa verbal sehingga menjadi "kata", tetapi masalah tubuh tidak pernah selesai dengan konsep, karena itu akan terus kembali pada "Tubuh" (Supartono, 2016: 209).

Tony Broer memosisikan tubuh sebagai bahan yang mempresentasikan subyek. Gagasan tubuh menjadi suatu hal yang berkenaan bentuk presentasi yang menyentuh berbagai bidang, misalnya politik praktis. Di sini, Tony Broer mempresentasikan politik tubuh.

Sebagaimana tubuh dipresentasikan berdasarkan keahlian, kemampuan, keterampilan yang mumpuni. Kendali tubuh yang dilakukan sistem politik tubuh yang lebih berkuasa, dan hal demikian menghipnotis penonton, sehingga yang terlihat bukan penggambaran yang lain atau bentuk imajinatif, 
tetapi apayang terlihat adalah kenyataan sebagai bentuk yang di abolisi.

Tony Broer berusaha lepas dari bahasabahasa verbal peristiwa yang disampaikan dalam bentuk representasi, atau metode penyampaian melalui teks verbal. Bentuk presentasi politik tubuh dibuat untuk menyingkirkan model tekstual yang lama. Lebih tepatnya, pada peristiwa $T u(m) b u h$ karya Tony Broer, tubuh diposisikan dalam status primer/subyek dengan bentuk presentasi politik tubuh, disitulah letak politisnya.

\section{SIMPULAN}

Fakta politik tubuh ternyata berhasil memasuki ruang-ruang seni pertunjukan, khususnya pertunjukan teater. Hasil-hasil yang ditemukan dalam penelitian ini menunjukkan bahwa dalam perwujudan tubuh yang dibawakan, dalam hal ini oleh Tony Broer sebagai subyek yang diteliti, merupakanpembawaan konsep politik tubuh yang dilakukan dalam konteks praktik teater. Peristiwa Tu(m)buh sebagai sampelpenelitian menghasilkan bukti konkrit mengenai fenomena politik tubuh dalam peristiwa teater.

Dalam konteks peristiwa $\mathrm{Tu}(\mathrm{m}) \mathrm{buh}$ karya Tony Broer, tubuh hadir melampaui kekuatan kata, melampaui dominasi teks verbal dari kata. Dengan adanya politik tubuh, maka peristiwa teater $T u(m) b u h$ memperlihatkan hirarki elemen-elemen pertunjukan yang didominasi oleh kekuatan tubuh. Presentasi politik tubuh merupakan cara mengeksistensikan tubuh dalam peristiwa teater, ketika tubuh dalam konteks teater berada pada tataran yang setara dengan kata-kata.

Dengan demikian, ekspresi ketubuhan yang diolah adalah penggambaran kondisi atau fenomena/realita berupa wacana politik tubuh. Kecuali Tony Broer, tidak ada orang yang berupaya keluar dari model/ gagasan penggarapan peristiwa yang lama dengan menawarkan metode presentasi politik tubuh serta menempatkan tubuh berada pada konsep pengalaman politik tubuh.

Penulis berpendapatbahwakontruksitubuh yang dibangun berupaya untuk menunjukkan sisi tubuh yang lebih dominan dan penggunaan tubuh secara konsisten. Tony Broer dalam peristwa teater $\mathrm{Tu}(\mathrm{m}) b u h$ memberikan persepsi penyadaran terhadap kehadiran tubuh serta memberikan dorongan yang melebihi terhadap kekuatan tubuh. Dalam pelaksanaan praktik kerja teaternya, dia menumbuhkan dan melahirkan citra identitas berupa politik tubuh.

Penggunaan politik tubuh ditampakkan pada perilaku keseharian yang kemudian ditransformasikan ke dalam peristiwa teater. Perihal politik tubuh tersebut berangkat dari perilaku Tony Broer yang memperdalam konsep teater tubuh, sehingga menunjukkan kekuatan fisikal tubuh. Hasil kontruksi tubuh Tony Broer berupa pendisiplinan dan pembentukan tubuh yang intens, keras, dan radikal. Tindakan Tony Broer tersebut melahirkan konsep dan nilai praktis yang lebih dominan dari penampakan politik tubuh, baik terhadap diri sendiri maupun orang lain, sehingga peristiwa teater $\mathrm{Tu}(m) b u h$ adalah sumbangsih bentuk penyajian dengan citra politik tubuh (tubuh yang bernuansa politis).

\section{Daftar Pustaka}

Artaud, A. (1994). The theatre and its double, diterjemahkan oleh Max Arifin (2009). Teater dan Kembarannya. Jawa Timur: Dewan Kesenian Jawa Timur.

Denissa, Y. A. Piliang, P. Widodo, N.Y.D. Adidsasmito. (2016). Fenomena Intertekstual Fashion Karnaval di Indonesia. Panggung, 26 (4), 430-443.

Faulks, K. (1999). Political Sociology: A Critical Introduction, diterjemahkan oleh Helmi Mahadi dan Shohifullah (2012), Sosiologi Politik Pengantar Kritis. Bandung: Nusa Media. 
Foucault, M. (1997). Disiplin Tubuh, (penyadur Petrus Sunu Hardiyanta), Yogyakarta: LKIS.

(1975), As Surveiller et Punir: Naissence de la Prison, diterjemahkan oleh Alan Sheridan (1995), Disclipine and Punish: The Birth of the Prison. New York-Canada: Random House in New York \& Random House Canada Limited.

Hardiansyah, A. (2012). Seni Disiplin Tubuh dalam Perspektif Michel Foucault. Substantia, 14 (1), 63-72.

Haryatmoko. (2016). Membongkar Rezim Kepastian Pemikiran Kritis Post-Strukturalis. Yogyakarta: PT Kanisius.

Kamahi, U. (2017). Teori Kekuasaan Michel Foucault: Tantangan bagi SosiologiPolitik. Jurnal Al-Khitabah, III (1), 117133.

Mustofa, M. (2017). Analisis Disiplin dan Kuasa Tubuh Michel Foucault dalam Kehidupan Santri Pondok Kebon Jambu Al-Islamy Pesantren Babakan Ciwaringin Cirebon. YAQZHAN: Analisis Filsafat, Agama, dan Kemanusiaan, 3 (1), 158-172.
Mudhoffir, A. M. (2013). Teori Kekuasaan Michel Foucault: Tantangan bagi Sosiologi Politik. MASYARAKAT, 18 (1), 75-100.

Ratna, N. K. (2010). Metodologi Penelitian Kajian Budaya dan Ilmu-Ilmu Sosial Humaniora pada Umumnya. Yogyakarta: Pustaka Pelajar.

Raditya, A. (2014). Sosiologi Tubuh: Membentang Teori di Ranah Aplikasi. Yogyakarta: Kaukaba.

Sahid, N. (2016). Semiotika untuk Teater, Tari, Wayang Purwa, dan Film. Semarang: Gigih Pustaka Mandiri.

Sitorus, E. D. (2002). The Art of Acting: Seni Peran untuk Teater, Film, dan TV. Jakarta: PT Gramedia Pustaka Utama.

Supartono, T. (2016). Penciptaan Teater Tubuh. Panggung, 26 (2), 208-221.

Syahputra, I. (2013). Rezim Media, Pergulatan Demokrasi, Jurnalisme, dan Infotainment dalam Industri Televisi. Jakarta: PT. Gramedia Pustaka Utama.

Synnott, A. (1993). The Body Social: Symbolism, Self and Society diterjemahkan oleh Pipit Maizier, (2007), Tubuh Sosial: Simbolisme, Diri, dan Masyarakat. Yogyakarta: Jalasutra. 